\title{
Spatial and temporal variations in nutrient limitation of seagrass Posidonia oceanica growth in the NW Mediterranean
}

\author{
Teresa Alcoverro ${ }^{1}$, Javier Romero ${ }^{1, *}$, Carlos M. Duarte ${ }^{2}$, Nancy I. López $^{3}$ \\ 'Departament d'Ecologia, Universitat de Barcelona, Avgda Diagonal 645, E-08028 Barcelona, Spain \\ ${ }^{2}$ Centre d'Estudis Avançats de Blanes, CSIC, Camí de Santa Bàrbara s/n, E-17300 Blanes, Girona, Spain \\ ${ }^{3}$ Laboratorio de Genética Bacteriana, Departamento de Química Biológica, Facultad de Ciencias Exactas y Naturales, \\ Universidad de Buenos Aires, 4to. Piso. Pabellón II, Ciudad Universitaria, 1428-Buenos Aires, Argentina
}

\begin{abstract}
The extent and seasonality of nutrient limitation of Posidonia oceanica (L.) Delile in the Costa Brava littoral (NW Mediterranean) in 5 meadows was investigated by means of repeated nutrient additions along a year cycle. Nutrient additions had a modest effect on leaf growth. The response to fertilization varied considerably among meadows, with those meadows consistently maintaining low (300 $\mu \mathrm{M}$ dissolved inorganic nitrogen and $9 \mu \mathrm{M}$ soluble reactive phosphorus) dissolved inorganic nutrient concentrations in sediment pore waters showing the greatest response to fertiluzation. The seasonality of the growth response to fertilization was consistent with calculated nutrient deficiencies, which were greatest in late spring and summer. Nutrient deficiency was alleviated in the fall, partially due to reduced growth, but aiso to nutrient reclamation from old leaves, which represented $20 \%$ and $18 \%$ of the annual nitrogen and phosphorus incorporation, respectively. The relative deficiency of nitrogen and phosphorus differed among sites, with the highest response found in P-deficient meadows. Nutr1ent limitation of $P$. oceanica meadows was greatest in late spring and summer, but differed greatly in magnitude and nature (nitrogen vs phosphorus) depending on local nutrient regimes.
\end{abstract}

KEY WORDS: Nitrogen Phosphorus - Growth S Seasonality Retranslocation

\section{INTRODUCTION}

Seagrass growth and production are often limited by nutrients, both in tropical and temperate systems (Harlin \& Thorne-Miller 1981, Orth \& Moore 1986, Dennison 1987, Short 1987, Powell et al. 1989, Short et al. 1990, Pérez et al. 1991, 1994, Fourqurean 1992. Fourqurean et al. 1992). The role of mutrients in controlling seagrass growth has been evaluated through the assessment of the nutritional status of their tissues (e.g. Duarte 1990, Fourqurean et al. 1992), the analysis of nutrient budgets (e.g. Patriquin 1972, Bulthuis \& Woelkering 1981, Pedersen \& Borum 1993), models (Zimmerman et al. 1987), and nutrient addition experiments (e.g. Powell et al. 1989, Short et al. 1990, Pérez

\footnotetext{
- Addressee for correspondence

E-mail: romero@porthos bio.ub.es
}

et al. 1991). The most conclusive evidence is provided by in situ nutrient additions; however, most studies have been conducted during short summer periods only and hence cannot elucidate the extent of seasonal variation in nutrient limitation.

Yet, available evidence points to the existence of seasonality in the extent of nutrient limitation in temperate seagrass ecosystems. The nutrient supply necessary to sustain rapid seagrass growth may not be available in spring and summer, yielding nutrient-limited midsummer seagrass growth, as observed in different Atlantic (Orth 1977, Harlin \& Thorne-Miller 1981), Mediterranean (Pérez et al. 1991, 1994) and Caribbean (Powell et al. 1989, Short et al. 1990) seagrass species. Nutrient limitation is probably alleviated in winter, when slower seagrass growth reduces nutrient demands (Pedersen \& Borum 1993), although there are insufficient data as yet to test this hypothesis. 
Nutrient storage may be important in winter, when nutrient supply may exceed demands (cf. Pedersen \& Borum 1993), allowing nutrient retranslocation to be an important component of the annual nutrient budget (Patriquin 1972, Borum et al. 1989, Pérez-Llorens \& Niell 1989, Hemminga et al. 1991, Pedersen \& Borum 1992).

Posidonia oceanica (L.) Delile is the dominant seagrass species in the Mediterranean (Den Hartog 1970) where it often grows under nutrient concentrations (e.g. López et al. 1995) low enough to limit other seagrass species (Cymodocea nodosa; Pérez et al. 1991, 1994). The seasonal growth pattern of $P$ oceanica appears to be controlled mainly by light and temperature, although there is indirect evidence of possible nutrient limitation, particularly in nutrient-poor meadows (Alcoverro et al. 1995). P. oceanica tissues have high nutrient concentrations in winter which decline subsequently with increasing plant growth towards summer (Alcoverro et al. 1995), suggesting seasonality of nutrient limitation.

Here we present the test of 2 hypotheses concerning nutrient limitation, (1) the existence of an overall nutrient limitation of Posidonia oceanica growth in meadows in the Costa Brava, NW Mediterranean, and (2) the increase in the extent of nutrient limitation from winter to summer, and an analysis of the spatial (i.e. among meadows) variability of such limitation and a preliminary budget of nutrient dynamics of the plant summarizing its various elements (i.e. requirements, deficiency, internal vs external sources) to support the experimental results.

\section{METHODS}

Study sites. The experimental nutrient addition was conducted in 5 monospecific Posidonia oceanica meadows along the NE coast of Spain. Three of the sites (Port Lligat, Giverola and shallow Medes) were located towards the up-slope limit of the meadows $(-5.0 \mathrm{~m})$. and the rest (deep Medes and Blanes) were closer to the deep limit $(-13.0 \mathrm{~m})$. A parallel work performed on the same sites and during the same period (Alcoverro et al. 1995, López et al. 1995) showed a seagrass growth pattern with a maximum in spring (May-June) and a minimum in late summer (August-September). Leaf nutrient concentrations also showed a consistent seasonality, with an increase during winter and a decline in late summer (Alcoverro et al. 1995). Nutrient concentrations in sediment pore water were very low ( $<2 \mu \mathrm{M}$ phosphate, $<100 \mu \mathrm{M}$ ammonium) from spring to summer, with substantial differences among meadows. The highest concentrations were found at the deep Medes and Port Lligat stations and the lowest concentrations at Blanes and Giverola (López et al. 1995). The sediments of Port Lligat and deep/shallow Medes had the highest concentrations of organic matter $(65.27 \pm 40.0,42.02 \pm 16.8$ and $41.83 \pm 7.1 \mathrm{mg} \mathrm{OM}$ $\left.\mathrm{cm}^{-3}\right)$ and the lowest redox potential $(-88 \pm 56,98 \pm 23$, $74 \pm 16 \mathrm{mV}$ ) while the sediments in Giverola and Blanes presented low organic matter $(25.94 \pm 5.75$, $19.26 \pm 9.07 \mathrm{mg} \mathrm{OM} \mathrm{cm} \mathrm{cm}^{-3}$ and high redox potential $(630 \pm 50 \mathrm{mV}$, no data on redox potential from the Blanes site).

Nutrient addition experiments. At each one of the 5 sites, two $1 \mathrm{~m}^{2}$ experimental plots were established, one used as a control and the other enriched at intervals of about $40 \mathrm{~d}$ during a year (i.e. 8 to 11 sampling events depending on the station, from October 1990 to January 1992). At each sampling time the sediments at the treatment plots were enriched by inserting 30 slow-release complete fertilizer sticks (commercial sticks manufactured by AMOSA, Spain), representing a load of about $6.5 \mathrm{~g} \mathrm{~N}$ and $1 \mathrm{~g} \mathrm{P} \mathrm{m}^{-2}$ each time. This ensured a N:P atomic supply of 14 , which is close to the apparent requirements for balanced seagrass growth (Duarte 1990). Ten shoots per plot were marked on each visit to estimate leaf growth using the method of Romero (1989) which is a modified Zieman (1974) method. All leaves within a shoot were marked together by punching 2 parallel holes just above the ligula of the outermost leaf with a hypodermic needle. The shoots marked in the previous visit were collected and transported to the laboratory within 2 to $3 \mathrm{~h}$ after collection.

Harvested shoots were rinsed and epiphytes were removed with a razor blade. Elongation and total length of each leaf were measured to the nearest $\mathrm{mm}$ and the leaf material was then dried at $70^{\circ} \mathrm{C}$ and weighed to obtain the growth and biomass of each shoot. Subsamples of young tissue (the growing new leaf tissue), old tissue (the oldest leaf in the shoots), intermediate leaves, and sheaths were used for $N, P$, and $\mathrm{C}$ analysis.

No efforts were made to estimate belowground growth, because the slow growth of Posidonia oceanica rhizomes (approx. 1 to $2 \mathrm{~cm} \mathrm{yr}^{-1}$; Pergent et al 1989) precludes detection of growth responses to fertilizers during the experimental term (1 yr).

Total carbon and nitrogen were determined using a Carlo-Erba NA1500 CHN Analyzer and phosphorus was determined after wet acid digestion by inductively coupled plasma atomic emission spectrometric (ICPAES) techniques (Mateo \& Sabaté 1993).

The loss rate of leaf biomass (LB, $\mathrm{g}$ dry wt shoot ${ }^{-}$ $\mathrm{mo}^{-1}$ ) was calculated as

$$
L B_{t+1}=B_{t}-B_{t+1}+P_{t+1}
$$

where $B_{t}$ and $B_{t+1}$ are the average shoot biomass ( $g$ dry 
wt shoot ${ }^{-1}$ ) at the beginning and at the end of a month respectively and $P$ is the production during this period (g dry wt shoot ${ }^{-1} \mathrm{mo}^{-1}$ ).

Nutrient requirements were calculated as the product of nutrient-sufficient seagrass leaf production, using growth rates, and the nutrient concentrations of fertilized plants. Nutrient incorporation (net amount) associated with growth was calculated as the product of leaf production and the nutrient concentrations in fully grown control leaves. Nutrient retranslocation from photosynthetic material was determined following Pedersen $\&$ Borum (1993) as the difference at time $t$ in the nutrient concentration between total leaves and old leaves multiplied by the monthly biomass lost $\left(L B_{i+1}\right)$. Nutrient deficiency was calculated as the difference between nutrient requirements and incorporation.

The significance of the response to nutrient addition at each month and station was obtained using a Wilcoxon matched pair test with unreplicated treatments (each value is represented by the averaged data of 10 replicate shoots) for each station and month to estimate the within-site, within-month and total overall growth effects.

For each site and at each sampling interval, differences between control and fertilized plots were tested using a Mann-Whitney $U$-test.

In the case of nutrient concentrations in leaves, we had only a single data value per plot and sampling; to test differences between control and fertilized plots, we also used the Wilcoxon matched pair test within each site (within-site effect) and using data from all sites (overall effect)

\section{RESULTS AND DISCUSSION}

Nutrient additions enhanced shoot elongation, but only at some sites and at some sampling events ( $\mathrm{p}=$ 0.006 , Fig. 1). The response to fertilization varied greatly among meadows. Within-site overall response (i.e. differences among control and fertilized) was only found at Blanes and Giverola (Fig. 1a, b; Wilcoxon, p = 0.017 and $p=0.011$, respectively); at these 2 sites, annual growth was incremented by nutrient addition by $40 \%$ and $30 \%$, respectively (control vs fertilized). In contrast, plants at the other 3 stations did not show a significant growth (or size) increment on an annual basis (Wilcoxon, $p>0.05$ ). Yet, leaf growth in fertilized
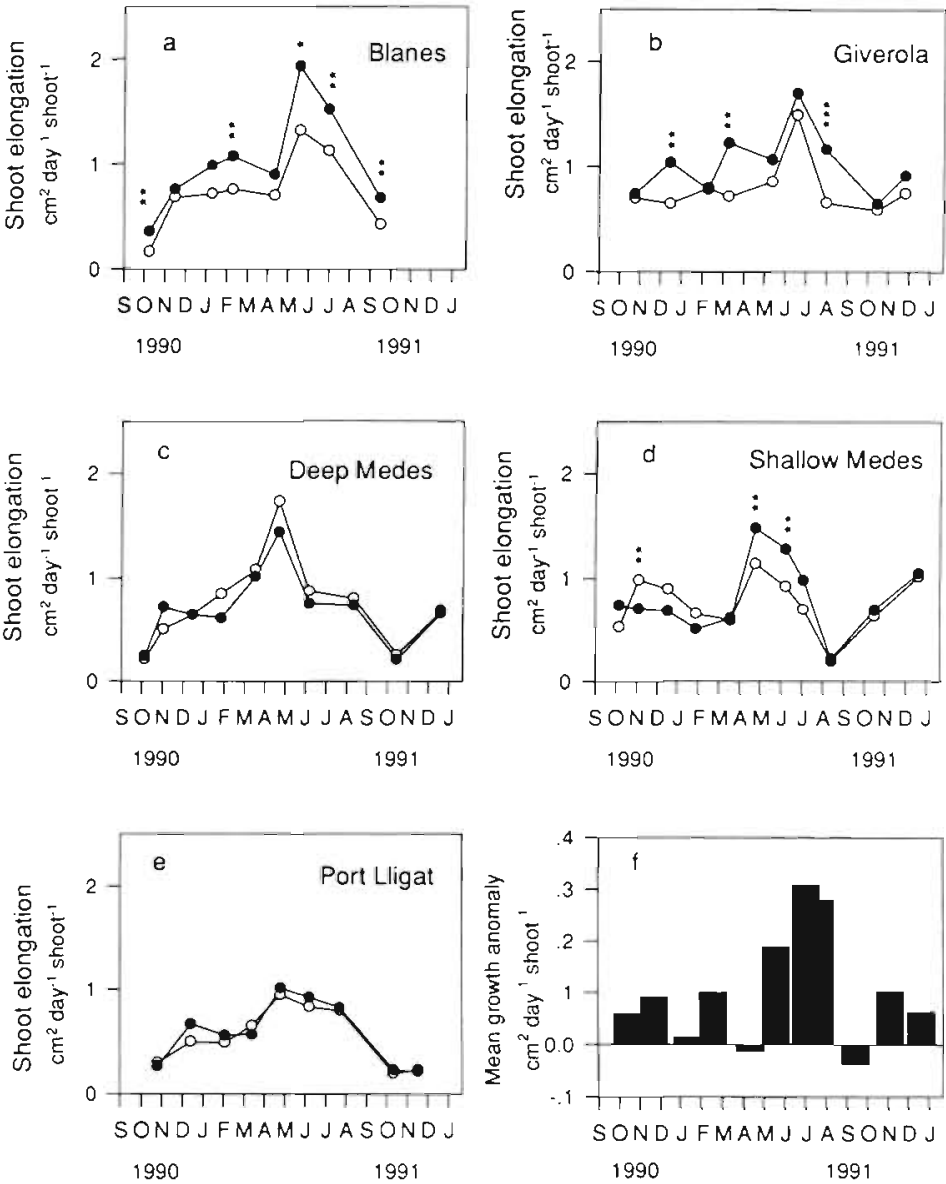

Fig. 1. Posidonia oceanica. (a to e) Seasonal changes in shoot elongation in control (o) and fertilized (•) plots at the 5 sites studied. (f) Mean growth anomaly relative to control (average growth in fertilized plots minus average growth in control plots). Asterisks indicate values signif-

icantly different from zero ( $\left.\cdots p<0.001,{ }^{\cdots} p<0.01, \cdot p<0.05\right)$

plots of shallow Medes was higher than in control plots in early summer (April-July; Fig. 1d), whereas no significant growth increase was observed at any time of the year for plants at deep Medes and Port Lligat (Fig. 1c, e).

The variability among sites in the extent of the annual growth increment appears to depend more on the nutrient concentrations in the pore water than on the leaf nutrient concentrations. The differences in growth response among meadows was well predicted by the number of sampling events with sediment pore water nutrient concentrations below median values, which were $300 \mu \mathrm{M}$ dissolved inorganic nitrogen (DIN) and $9 \mu \mathrm{M}$ soluble reactive phosphorus (SRP). There were strong correlations between the number of sampling events with SRP and DIN concentrations in pore water below these median values and the response of the plants at the different meadows to fertilization (as increase in annual growth relative to control: $R=0.86$ 


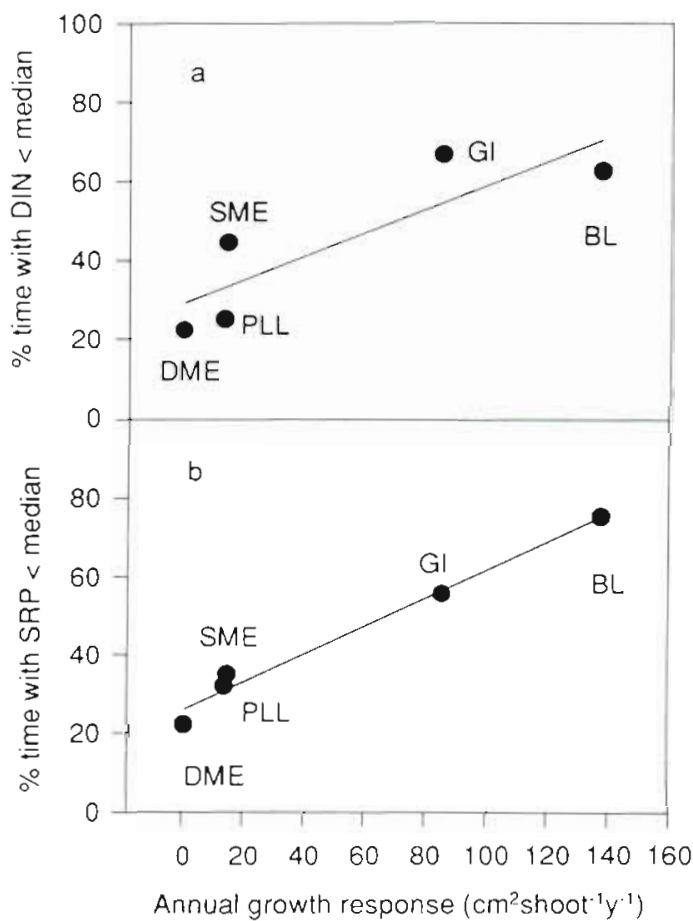

Fig. 2. Posidonia oceanica. Relationship between the fraction of the time (as the percent of the number of sampling events) with pore water nutrient concentrations below the overall median values $(300 \mu \mathrm{M}$ dissolved inorganic nitrogen, DIN, and $9 \mu \mathrm{M}$ soluble reactive phosphorus, SRP) and the increase in annual growth following fertilization (fertilized minus control\}. Sites: Blanes (BL), Giverola (GI), deep Medes (DME), shallow Medes (SME), Port Lligat (PLL)

for DIN, $p<0.05 ; R=0.99$ for SRP, $p<0.01$; Fig. 2a, b). Thus, relatively long periods under low nutrient concentration are probably the cause of reduced growth.

Major differences between control and fertilized plots were found in late spring-summer (Fig. 1). This finding corresponds with low summer nutrient concentrations in the interstitial waters, which decrease below $100 \mu \mathrm{M}$ for ammonium and $1 \mu \mathrm{M}$ for phosphate, values which are considered to be limiting for seagrass growth (Fourqurean 1992). This seasonal response suggests a shift from growth control by light and temperature during winter to nutrient-limited summer growth (Fig. 1f), which is consistent with results for other temperate seagrass species (e.g. Cymodocea nodosa, Pérez et al. 1991; Zostera marina, Orth 1977. Harlin \& Thorne-Miller 1981, Short 1987. Murray et al. 1992, Pedersen \& Borum 1993; Heterozostera tasmanica, Bulthuis \& Woelkerling 1981, Bulthuis et al. 1992). Nutrient-limited seagrass growth in summer results from increased nutrient demand by the seagrasses (Pedersen \& Borum 1993; see below), low nutrient availability and competition for nutrients with other organisms, mainly bacteria (cf. López et al. 1995).
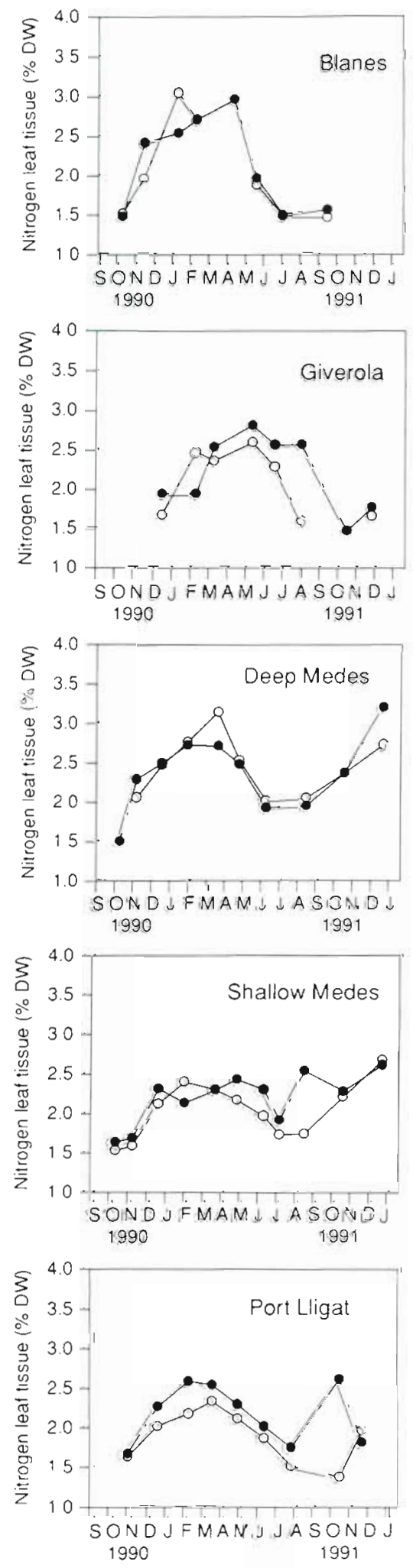

Fig. 3. Posidonia aceanica. Seasonal changes in the nitrogen concentration in leaves from control $(0)$ and fertilized $(\bullet)$ plots at the 5 sites studied. Differences between control and fertilized plots were significant at Port Lligat $(p=0.002)$ and weakly significant at Giverola $(p=0.09)$ and shallow Medes $(p=0.08)$ 
The nitrogen concentration in leaves of fertilized plants also increased in response to nutrient additions; an overall effect was found (data from all sites pooled, $p=0.002$ ), although within-site nitrogen increase in leaves was only significant for Port Lligat $(p=0.01)$ and weakly significant for shallow Medes and Giverola ( $p=0.08$ and $p=0.09$, respectively) (Fig. 3). In contrast, carbon and phosphorus concentration did not show any significant response to the fertilization in any of the compartments studied ( $p>0.25$ in all cases). The lack of response of phosphorus tissue concentration to fertilization is in contrast with the increment observed in nitrogen concentration, as reported in the past in another enrichment experiment (Burkholder et al. 1994).

The nutrient concentration in leaves of control plants was low at Blanes and Giverola, where the response to fertilization was maximal, and was high in deep Medes, where no response was detected (Fig. 3). But, at the Port Lligat site, leaf nutrient concentration was low (particularly for nitrogen; Fig. 3) while sediment nutrient concentrations were relatively high (López et al. 1995), and no growth response to nutrient additions was observed (Fig. 3). This paradox suggest that the low tissue $N$ concentrations in plants at Port Lligat derives from internal constraints on nitrogen use, rather than low external availability. This may be associated with the low redox potential of Port Lligat sediments $(-88 \mathrm{mV}$ on average), compared with the rest of the stations, which may interfere with nitrogen assimilation in roots (Pregnall et al. 1987, Zimmerman et al. 1987).

Total net nitrogen incorporation by seagrass ranged between $0.13 \mathrm{mg}$ shoot ${ }^{-1} \mathrm{~d}^{-1}$ in April-May and $0.03 \mathrm{mg}$ shoot $^{-1} \mathrm{~d}^{-1}$ in October. Phosphorus incorporation was also greatest in spring $\left(0.011 \mathrm{mg}\right.$ shoot $^{-1} \mathrm{~d}^{-1}$ in AprilMay) and lowest (0.002 $\mathrm{mg}$ shoot $\left.^{-1} \mathrm{~d}^{-1}\right)$ in October (Fig. 4a, b). Nitrogen and phosphorus requirements were highest in summer (Fig. $4 \mathrm{a}$, b). Thus, nutrient deficiency was maximal in summer, ranging between 0 and $0.038 \mathrm{mg} \mathrm{shoot}^{-1} \mathrm{~d}^{-1}$ for nitrogen and between 0 and $0.0016 \mathrm{mg} \mathrm{shoot}^{-1} \mathrm{~d}^{-1}$ for phosphorus (Fig. 4c, d).

Nitrogen and phosphorus retranslocation from old leaves was substantial from July to December, with a maximum of $0.055 \mathrm{mg}$ shoot ${ }^{-1} \mathrm{~d}^{-1}$ for nitrogen and $0.0025 \mathrm{mg} \mathrm{shoot}^{-1} \mathrm{~d}^{-1}$ for phosphorus (Fig. 4e, f), observed during September-October when biomass losses are greatest (Alcoverro et al. 1995). Leaf nutrient retranslocation represented $20 \%$ and $18 \%$ of the annual nitrogen and phosphorus incorporation, respectively, similar to values found by Pedersen \& Borum (1992). Our estimates assume nutrient leaching to be negligible, a fact which has not been demonstrated for Posidonia oceanica but has been for other seagrasses (Borum et al. 1989, Pedersen \& Borum 1992). P. oceanica has massive rhizomes that can play a major role in nutrient economy by means of storage and retranslocation. Seasonal variation in nutrient concentration in the rhizome is substantial (Pirc \& Wollenweber 1988), which, added to the high biomass of the P. oceanica rhizomes, will potentially be an important source of nutrients. Accordingly, the fraction of the $P$. oceanica nutrient demand that can be met by internal supply is probably much higher than the 18 to $20 \%$ we report, which only represents leaf retranslocation.

The leaf concentrations of nitrogen and phosphorus appeared strongly correlated. The seasonal pattern of leaf concentrations of both nutrients are similar $(\mathrm{R}=$ $0.73, p<0.001)$. Seasonal patterns of nutrient deficiency were also similar for both elements $(R=0.84, p<$ 0.01 ), and no differential retranslocation occurred (correlation between nitrogen and phosphorus retranslocation: $\mathrm{R}=0.99, \mathrm{p}<0.001$ ). The relative deficiency of both elements differed among sites (Fig. 5). Relative to 


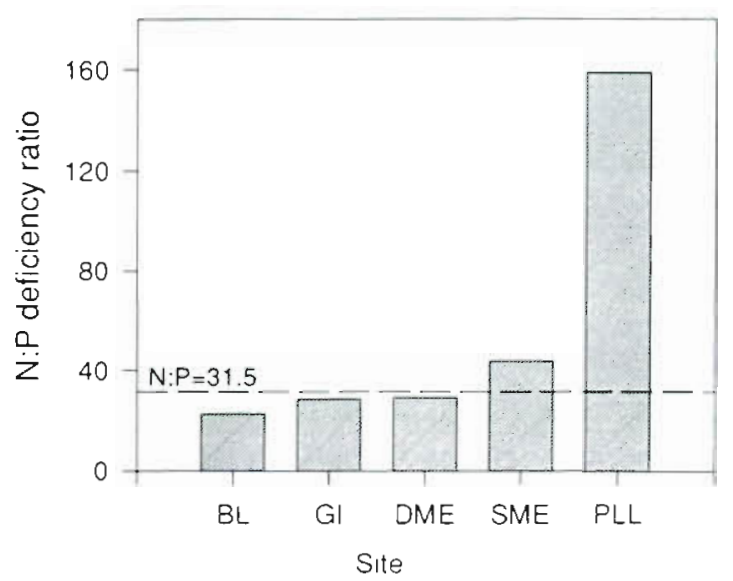

Fig. 5. Posidonia oceanica. Atomic ratio (N:P) of the average N and $P$ deficiency as derived from Fig. 4 for the 5 stations studied. Dashed line: average N:P ratio in fertilized plants

the N:P ratio of fertilized plants ( $\mathrm{N}: \mathrm{P}=31.5)$, those at Port Lligat, and to a lesser extent those in shallow Medes, appeared to be $\mathrm{N}$ deficient, whereas the N:P leaf ratio of plants at Blanes and Giverola suggested a strong $P$ deficiency.

The relative importance of nutrient sources in supplying Posidonia oceanica nutrient requirements (uptake from external pools and internal recycling) varied seasonally. Nutrient deficiency was high from May to October (Fig. 4), and this was reflected in the maximum growth response to fertilization (Fig. 1). In autumn (September-October), high nutrient reclamation from old leaves, together with a reduced growth related to requirements, alleviated nutrient deficiency (Fig. 4). During winter, $P$. oceanica accumulated nutrients, as reflected in the high leaf nutrient content (Fig. 3) as has been reported for macroalgae (Chapman \& Craigie 1977, Zimmerman \& Kremer 1986) and Zostera marina (Pedersen \& Borum 1993). Winter growth was, therefore, mostly limited by light and temperature (Alcoverro et al. 1995), and possibly by the pool of carbon stored in late summer (Pirc 1989, Alcoverro 1995), although in the meadows where nutrient limitation was more severe there was also a small response to the fertilization in the fall (Fig. 1f).

In summary, nutrient demands during winter appear to be met by external sources, which can exceed plant demands and thus allow storage. The increased nutrient requirements in spring can deplete sediment pore water nutrients, forcing internal nutrient reclamation in order to meet nutrient demands, with reclamation from leaves covering about $20 \%$ of the requirements, and that from rhizomes being possibly greater. This situation leads to significant nutrient limitation in late spring-early summer (i.e. Blanes, Giverola or shallow
Medes), which is alleviated in late summer by reduced growth rates (and thus nutrient demands) and nutrient reclamation from old leaves. Nevertheless, a high variability exists over this general pattern; for example, other (unknown) factors can override the role of nutrients (as probably occurs at Port Lligat), or plant growth may be permanently light limited in plants growing near the population depth limit (deep Medes).

Our analysis also shows that nutrient deficiency of NW Mediterranean Posidonia oceanica meadows may involve both $\mathrm{N}$ and $\mathrm{P}$, and suggests growth responses to nutrient additions to be greater for P-deficient plants.

Acknowledgements. This work was supported by the grant STEP-0063-C of the ECC. We thank M. A Mateo, N. Marbá and $\mathrm{J}$. Cebrián for their help in the field.

\section{LITERATURE CITED}

Alcoverro T (1995) Production ecology of the mediterranean seagrass Posidonia oceanica (L.) Delile. PhD thesis, University of Barcelona

Alcoverro T, Duarte CM. Romero J (1995) Annual growth dynamics of Posidonia oceanica: contribution of largescale versus local factors to seasonality. Mar Ecol Prog Ser 120:203-210

Borum J, Murray L, Kemp MW (1989) Aspects of nitrogen acquisition and conservation in eelgrass plants. Aquat Bot 35:289-300

Bulthuis DA, Axelrad DM, Mickelson MJ (1992) Growth of the seagrass Feterozostera tasmanica limited by nitrogen in Port Phillip Bay, Australia. Mar Ecol Prog Ser 89: $193-207$

Bulthuis DA, Woelkerling WJ (1981) Effects of in situ nitrogen and phosphorus enrichment of the sediments on the seagrass Heterozostera tasmanica (Martens ex Aschers.) den Hartog in Western Port, Victoria, Australia. J Exp Mar Biol Ecol 53:193-207

Burkholder JM, Glasgow HB Jr, Cooke JE (1994) Comparative effects of water-column nitrate enrichment on eelgrass Halodule wrighti, and widgeongrass Ruppia maritima. Mar Ecol Prog Ser 105:121-138

Chapman ARO, Craigie JS (1977) Seasonal growth in Lamlnaria longicruris: relations with dissolved inorganic nutrients. Mar Biol 40:197-205

Den Hartog $C(1970)$ The sea-grasses of the world. Verhand Kon Ned Akad Wetensch Afd Natuurkunde, Tweede Reeks deel 59 North-Holland Publ, Amsterdam

Dennison WC (1987) Effects of light on seagrass photosynthesis, growth and depth distribution. Aquat Bot 27:15-26

Duarte CM (1990) Seagrass nutrient content. Mar Ecol Prog Ser $67: 201-207$

Fourqurean JW (1992) Relationships between porewater nutrient and seagrasses in a subtropical carbonate environment. Mar Biol 114:57-65

Fourqurean JW, Zieman JC, Powell GVN (1992) Phosphorus limitation of primary production in Florida Bay: evidence from C:N:P ratios of the dominant seagrass Thalassia testudinum. Limnol Oceanogr 37:162-171

Harlin MM, Thorne-Miller B (1981) Nutrient enrichment of seagrass beds in a Rhode Island coastal lagoon. Mar Biol $65: 221-229$ 
Hemminga MA, Harrison PG, van Lent F (1991) The balance of nutrient losses and gains in seagrass meadows. Mar Ecol Prog Ser 71:85-96

López NI, Duarte CM, Vallespinós F, Romero J, Alcoverro T (1995) Bacterial activity in seagrass (Posidonia oceanica) sediments. J Exp Mar Biol Ecol 187:39-49

Mateo MA, Sabaté S (1993) Wet digestion of vegetable tissue using a domestic microwave oven. Anal Chem 279: $273-279$

Murray L, Dennison WC, Kemp WM (1992) Nitrogen versus phosphorus limitation for growth of an estuarine population of eelgrass (Zostera marina). Aquat Bot 44:83-100

Orth RJ (1977) Effect of nutrient enrichment on growth of the eelgrass Zostera marina in the Chesapeake Bay, Virginia, USA. Mar Biol 44:187-194

Orth RJ, Moore KA (1986) Effect of nutrient enrichment on growth of the eelgrass Zostera marina in the Chesapeake Bay, Virgmia, USA. Aquat Bot 24:335-341

Patriquin DG (1972) The origin of nitrogen and phosphorus for growth of the marine angiosperm Thalassia testudinum. Mar Biol 15:35-46

Pedersen MF, Borum J (1992) Nitrogen dynamics of eelgrass Zostera marina during a late summer period of high growth and low nutrient availability. Mar Ecol Prog Ser 80: $65-73$

Pedersen MF, Borum J (1993) An annual mitrogen budget for a seagrass Zostera marina population. Mar Ecol Prog Ser 101:169-177

Pérez M, Duarte CM, Romero J, Sand-Jensen K, Alcoverro T (1994) Growth plasticity in Cymodocea nodosa stands: the importance of nutrient supply. Aquat Bot 47:249-264

Pérez M, Romero J, Duarte C. Sand-Jensen K (1991) Phosphorus limitation of Cymodocea nodosa growth. Mar Biol $109: 129-133$

Pérez-Llorens JL, Niell FX (1989) Emergence and submergence effects on the distributional pattern and exchange of phosphorus in the seagrass Zostera noltii Hornem. Sci Mar 53:497-503

Pergent G, Boudouresque CF, Crouzet A, Meinesz A (1989)

This article was submitted to the editor
Cyclic changes along Posidonia oceanica rhizomes (lepidochronology): present state and perspectives. PSZN I: Mar Ecol 10:221-230

Pirc H (1989) Seasonal changes in soluble carbohydrates, starch, and energy content in mediterranean seagrasses. PSZN I: Mar Ecol 10:97-105

Pirc $H$, Wollenweber B (1988) Seasonal changes in nitrogen, free amino acids, and $\mathrm{C} / \mathrm{N}$ ratio in Mediterranean seagrasses. PSZN I: Mar Ecol 9:167-179

Powell GVN, Kenworthy WJ, Fourqurean JW (1989) Experimental evidence for nutrient limitation of seagrass growth in a tropical estuary with restricted circulation. Bull Mar Sci 44:324-340

Pregnall AM, Smith RD, Alberte RS (1987) Glutamine synthetase activity and free amino acid pools of eelgrass (Zostera marina L.) roots anoxia. J Exp Mar Biol Ecol 106: $211-228$

Romero J (1989) Primary production of Posidonia oceanica beds in the Medes Islands (Girona, NE Spain). In: Boudouresque CF, Meinesz A, Fresi E, Gravez V (eds) Internatıonal Workshop on Posidonia beds. GIS Posidonie, Marselles, 2:85-91

Short FT (1987) Effects of sediment nutrients on seagrasses: literature review and mesocosm experiment. Aquat Bot 27:41-57

Short FT, Dennison WC, Capone DG (1990) Phosphorus-limited growth of the tropical seagrass Syringodium filiforme in carbonate sediments. Mar Ecol Prog Ser 62:169-174

Zieman JC (1974) Methods for the study of the growth and production of turtle grass, Thalassia testudinum König. Aquaculture 4:139-143

Zimmerman RC, Kremer JN (1986) In situ growth and chemical composition of the giant kelp, Macrocystis pyrifera: response to temporal changes in ambient nutrient availabılıty. Mar Ecol Prog Ser 27:277-285

Zimmerman RC, Smith RD, Alberte RS (1987) Is growth of eelgrass nitrogen limited? A numencal simulation of the effects of light and nitrogen on the growth dynamics of Zostera marina. Mar Ecol Prog Ser 41:167-176

Manuscript first received: January 23, 1995

Revised version accepted: November 18, 1996 